\title{
GEÇ OSMANLI DÖNEMİ KENTSEL MEKANDA BATILILAŞMA ETKILERİ: KONYA MİLLET BAHÇESİ
}

\section{WESTERNIZATION EFFECTS IN LATE OTTOMAN PERIOD URBAN SPACE: KONYA NATION GARDEN}

Filiz ÇELIK*

\begin{abstract}
$\ddot{O} z$
Osmanl Imparatorluğu'nda, Tanzimat Fermanı'ndan Cumhuriyete kadar olan, 1839-1923 yilları arasında yaşanan modernleşme sürecini yönlendiren battlllaşma hareketi, başta devletin yönetimi olmak üzere eğitim, siyaset, sosyal, kültür, ekonomi ve yerleşimlere kadar her alanda kendini göstermiştir. Batılaşmanın etkileri, merkez-çevre ilişkili olduğu için öncelikle İstanbul'da yoğun olarak ön plana çıkmış; ancak Anadolu'daki kentlerde farklı düzeylerde de olsa yansımaları görülmüştür. Kentlerde mimariden sokakların fiziki yapısına; kent formundan açık-yeşil alanlara kadar kentin bütününde etkili olan değgişimler yaşanmıştır. Siyasi dönüşümlerin kent mekan üzerindeki etkileriyle yeşil alanların işlevi ve formu değişime uğramış; bu değişim ve dönüşüm yeşil alanlarda görünürlük kazanmıştır. Toplumsal dinamiklerin kent mekanına yansıdı̆̆ battlllaşma sürecinde batı tarzında yeni yeşil alanlar düzenlenmiştir. Fransa'daki Halk Bahçelerinden esinlenerek halka açık park ve bahçeler yapılmış; başta İstanbul olmak üzere diğer Osmanl kentlerinde de yer alan bu bahçelere "Millet Bahçesi" adı verilmiştir. Bu çalışmada; geç Osmanlı döneminde yeşil alanlarda değişim ve batıllaşma etkisi ile farklı kentlerde halkın kullanımına sunulan Millet Bahçesi hakkında açılama yapılmış; Osmanlı döneminde Konya'nın kentsel özellikleri ve Konya Millet Bahçesi hakkında bilgi verilmiştir.
\end{abstract}

\section{Anahtar Kelimeler}

Batılılaşma, bahçe, park, Millet Bahçesi, Konya.

\begin{abstract}
The westernization movement in Ottoman Empire from Tanzimat Edict to the Republic of Turkey, which led to the modernization process that took place between 1839 and 1923, has manifested itself in all fields from state administration to education, politics, social, culture, economy and settlements. Since the effects of westernization are related to the center-periphery, it first intensively became prominent in Istanbul. However the reflections at different levels in the cities of Anatolia were also observed. In the cities, effective changes were visible in whole city from architecture to the physical structure of streets, from city form to open green areas. With the effects of political transformations on urban space, the function and form of the green areas changed; this change and transformation gained visibility in green areas. In the westernization process in which the social dynamics are reflected in the urban space, new green areas were arranged in the western style.
\end{abstract}

* Dr. Öğr. Üyesi, Selçuk Üniversitesi Ziraat Fakültesi Peyzaj Mimarlığı Bölümü, filiz@selcuk.edu.tr 
Public parks and gardens were built, inspired by the Folk Gardens in France; these gardens, which were located in Istanbul and other Ottoman cities, were called "Nation Gardens". In this study; an explanation was made about Nation Gardens which was presented to the use of people in different cities with the effect of change and westernization in green areas during the late Ottoman period; also information was given about the urban features of Konya and the Konya Nation Garden during the Ottoman period.

\section{Keywords}

Westernization, garden, park, Native Garden, Konya. 


\section{GİRIŞ}

Kamusal alan, yalnızca modernitenin getirdiği yenilik ve değişimler için değil, mekansal olarak kentlerin ve sosyolojik olarak bireyin kendini nasıl ürettiğinin ve tanımladığının araştırılması için önemli bir alandır (Ünlü 2012: 251). Tanyeli'ye göre; yeşil alan toplumun kamusal alanlardaki yansımalarının görünür bir biçimidir (2005: 201). Bu doğrultuda park ve bahçeler, taşıdığı sembolik ve simgesel değerleriyle, var olduğu dönemde toplumun kentsel ve kamusal yaşam kültürünün yanı sıra bilinç düzeyini de aktarmaktadır. Böylece, kültürel peyzaj niteliği kazanmakta; bu niteliğini tarihsel düzlemin kültürel ve doğal değerleriyle sürdürebildiğinde tarihi kentsel peyzaj olarak korunması ve yaşatılması gerekmektedir (Turgut Gültekin 2015: 8).

Osmanlı'da yer alan kamusal mekanlardan ilki kahvehanelerdir. Hamam, cami ve külliye avluları ile mescit, çeşme, kahvehane çevresinde, pazarlarda veya sokakların genişlemesiyle oluşan, 'planlanmamış' kendiliğinden gelişmiş semt ve mahalle ölçeğindeki küçük meydanlar dönemin en önemli kamusal mekanlarıdır. Bunların yanı sıra bağ, bahçe ve korular da açık kamusal alan olarak kent dokusunda yer almıştır (Nalbant 2016: 19).

Toplumlar ve kültürleri değiştikçe, toplumların ortaklaşa ürettikleri kararların sonucu olan yapılı çevre de değişip dönüşmektedir (Koca 2005: 32). Geçmiş ve gelecek arasında bağlayıcı özeliğe sahip olan kültürlerin değişim ve gelişim süreçlerinin incelenmesi toplumlar hakkında önemli bilgiler vermektedir. Ancak konu bahçeler olduğunda yaşanan değişim ve gelişimin izlenmesi zorlaşmaktadır. Tarihi bina ve yapıların aksine bahçe, değişen ve zamanla gelişen bir nitelikte olduğu için tarihi Türk Bahçelerinin büyük bir kısmı günümüzde mevcut değildir. Bazıları tamamen yok olmuş; bazıları ise çok fazla değişikliğe uğradığı için özgünlüğünü yitirmiştir. Bu nedenle hem bahçeler hakkında bilgi sahibi olmak hem de bahçelerin kültürel miras olarak korunup geleceğe aktarılması mümkün olamamıştır (Çelik 2016: 30).

Osmanlı'da yapılaşmış çevrenin müdahale edilebilir bir olgu olduğu 18. yüzyılda ortaya çıkan modern bir anlayışa işaret etmektedir. Osmanlı'nın batılılaşma süreci, toplumsal dinamiklerin kent mekanına yansıdığı, değişim ve dönüşümün görünürlük kazandığı bir zaman dilimidir. Bu dönemdeki dönüşümün ideolojik açıklaması, kamu otoritesinin dönüştürücü, değiştirici ve modernleştirici tek güç olduğudur. Kentsel düzenlemeler içinde yeni yeşil alanların oluşturulmasında estetik boyutla birlikte devletin kendini gösterme çabası da etkili olmuştur (Nuhoğlu vd. 2016: 5).

Osmanlı döneminde, açık kamusal mekan olarak halkın kullanımına sunulan bağ, bahçe ve korular, kentlerin eğlence, sosyal ve kültürel yaşam merkezi olmuştur. Bu bağlamda bağ, bahçe ve korular, halkın sosyal ve kültürel etkileşimi, gelişimi ve değişimini sağlayan kilit alanlardır. Batılılaşma ile geleneksel toplumdan modern topluma geçişte yeşil alanlar, anlamsal, şekilsel ve işlevsel açıdan farklılaşmıştır. Batılılaşmanın etkisi ile Selçuklu ve Osmanlı'dan gelen bağ ve bahçe kültürü yerini mesire yeri ve park kavramına bırakmıştır. Bu çalışmada, Osmanlı modernleşmesinin kamusal mekanlardaki yansıması olan Millet Bahçesi hakkında bilgi verilmiştir.

\section{OSMANLI DÖNEMINDE YEŞİL ALANLARDA DEĞİŞIM}

İstanbul'un uzun süre ve en son Osmanlı başkenti olması, kentte siyasi, ekonomik, teknolojik, sosyal ve kültürel gelişim, değişim ve dönüşümlerin mekansal etkilerini 
yansıtmaktadır. Osmanlı sınırlarındaki diğer kentlerde de yaşanan dönemsel gelişim, değişim ve dönüşümleri İstanbul ile paralel olarak az da olsa görmek mümkündür. Bu nedenle mevcut verilerin çokluğu ve doğruluğu nedeniyle Osmanlı döneminde yeşil alanlar konusundaki bilgilerin çoğu İstanbul'un yeşil alanları ve yeşil alanlardaki gelişim, değişim ve dönüşümler üzerinden açıklanabilir.

Hem Selçuklular hem de Osmanlılar Anadolu'ya beraberlerinde kendi doğu kültürlerini de taşımışlardır. Bu öğelerin başında da "Bahçe Kültürü" gelmektedir. Osmanlı'da bahçenin en doruğa çıktığı dönem, Edirne'nin başkent olmasıyla başlamıştır. Başta Edirne olmak üzere bütün Trakya'da kentler bir bahçe sistemi üzerine inşa edilmiştir. Başkentin İstanbul'a taşınmasıyla yavaş yavaş batı etkisine giren Osmanlı, sonuçta kendi kültüründen gelen bahçeleri terk ederek batıda gelişen park sistemlerine yönelmiştir (Memlük 2013). İstanbul'da yeşil alan kullanımı, Osmanlı'nın sosyal ve kültürel yapısının etkisiyle ev, saray, köşk ve kasır bahçeleri gibi özel alanlarda yoğunlaşmış, halka açık alanlar ise korular ve mesire yerleri şeklinde görülmüştür. İstanbul bahçeleri, doğal olarak Doğu ve Batı bahçe mimarlığının ilkelerini özümsemiş, taklit etmiş ve yeniden yaratmış, aynı zamanda bir başkent modası oluşturarak imparatorluğun dört bir köşesine yayılmış, yeni sentezlerin doğmasına imkan vermiştir (Özgüç Erdönmez-Aydoğdu Ünlü 2009: 37).

Geleneksel Osmanlı dünyası için yeşil alan kavramının ağırlıklı olarak açık bir sahayı ya da tasarlanmamış doğal yeşil alanı tanımladığı anlaşılmaktadır. Bu bağlamda modernleşme hareketlerinin her alanda hissedildiği II. Meşrutiyet'e kadar doğal olarak bir park kavramından söz etmek mümkün değildir. XVII. yüzyıla kadar İstanbul'un etrafında oluşturulan bütün mesire alanlarının aslında padişah için düzenlenmiş av bahçeleri ile saray görevlilerinin köşklerini içeren alanlar olduğu görülmektedir (Gürkaş 2003: 175).

Osmanlı tarihinde "Lale Devri" olarak adlandırılan ve 1718-1730 yılları arasını kapsayan kısa süreç, özellikle güzel sanatlar açısından çok verimli bir dönemdir. Şiir edebiyat, müzikte, sivil mimari ve özellikle de yeşil alanların formu ve kullanımında büyük değişim ve yenilikler söz konusu olmuştur. Türk bahçe sanatı bu dönemde çok büyük bir gelişim yakalamıştır. Lale Devri ile Osmanlı, geleneksel "bahçe" uygulamasından, batının toplumu dönüştürme ve sosyalleştirme adına çok güçlü bir biçimde kullandığı "park"a geçiş yapmıştır. Özellikle akarsu vadilerinin düzenlenmesiyle daha çok gezinti amaçlı kullanımlara olanak sağlayan bu alanlar içinde ön plana çıanlar İstanbul'daki Göksu ve Kağıthane Dereleridir (Fotoğraf 1). Kağıthane'de inşa edilen bağlar ve bahçeler döneminin doruk bahçe eserleri olarak önem taşır (Memlük 2013). Lale devri Konya'sı da bağ ve bahçeler ortasında şirin bir şehir görünümündedir (Muşmal 2016: 131). 

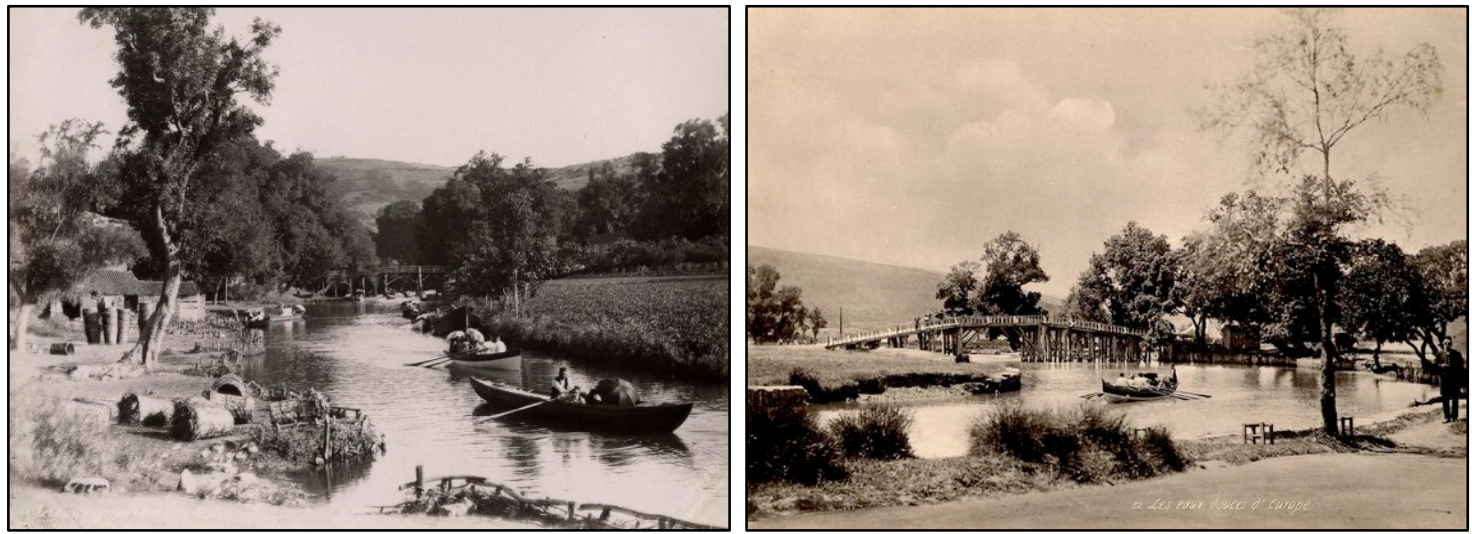

Fotoğraf 1. Göksu ve Kağıthane Dereleri (Eski İstanbul Fotoğrafları Arşivi)

Değişimin merkez-çevre ilişkili olduğu pek çok modernleşme hareketinde olduğu gibi, Osmanlı devletinde kamu diplomasisini yönetenler sadece siyasi, idari ve iktisadi alanlarda değil, reform döneminin özünde bulunan müdahaleci ve yönlendirici etkisiyle, toplumsal normların değişiminde de ana aktör vazifesini görmüştür (Kiraz 2018: 5). Osmanlı döneminde modernleşme hareketinin ilk adımları Tanzimat fermanıyla atılmıştır. Osmanlı İmparatorluğu'nda, 1839 yılında Tanzimat'ın ilanıyla başlayan ve toplumu Batılılaştırma doğrultusunda girişilen reformlar kent mekanını da etkilemiştir. Batılı ilkelere ve uygulamalara göre yapılan düzenlemeler, Osmanlı kentine ve kentlerin dönüşümüne ilişkin daha küresel düşüncelere ulaşmayı sağlayacak bazı dikkat çekici özellikler taşımaktadır (Özgüç ErdönmezAydoğdu Ünlü 2009: 37). Kente bütüncül bir müdahalenin olmadığ1 Osmanlı geleneksel dünyasında Kağıthane düzenlemeleriyle bir kırılma noktası yaşanmıştır. XVIII. yüzyılın ilk yarısında İstanbul'un en önemli kentsel gelişmelerinden biri, Kağıthane'de oluşturulan ve üst sınıflara yönelik olan, "sahte banliyöleşme" hareketidir. Ancak Türk üst sınıfının yararlandığı yazlık evler için alternatif kentsel alanlar oluşturmanın hiçbir batılılaşma ile ilgisi yoktur. Aksine, bu durum Konya ve Kayseri gibi Anadolu kentlerinde yüzyıllardır bilinen bir uygulamadır (Gürkaş 2009: 173).

İstanbul'un öncülüğünde kentsel mekanda radikal dönüşümler, açı-yeşil alanlarda da başlatılmıştır. Böylece, sarayların avlu ve has bahçeleri, Boğaziçi bahçeleri ve konut bahçeleri gibi özel alanlar dışında, doğal yeşil alan olan mesire yerlerinin yanı sıra planlı bahçeler de halkın ortak kullanımına açılmıştır (Gürkaş 2003: 25).

Batı kültürünün etkisinden önce, Türk Bahçesi; düzenin yalınlığı, yaşam mekanı olması ve işlevselliği ile tanımlanmaktadır. Osmanlı Döneminde XVIII. yüzyılın ikinci yarısından itibaren batı kültürünün etkisiyle avlu ve bahçeler doğallıktan uzaklaşmaya, daha biçimsel bir nitelik kazanmaya ve estetik ön plana çıkmaya başlamıştır. Bu dönemde halka açık mesire yerleri, korular ve bahçeler düzenlenmiştir (Eldem 1976: 52). Park ve mesire, aynı zamanda geleneksel başka normları da yıkmakta, yeni lüksler tanımlamakta ve ancak bazı yeni lüksler sayesinde varlık kazanmaktadır. Bu bağlamda özel araba sahipliği, anahtar kavram haline gelmiştir (Tanyeli 2005: 155). XIX. yüzyılın sonu ile XX. yüzyılın başlarında artan ulaşım imkanları sayesinde birçok yeni mesire alanı oluşmuştur (Gürkaş 2003: 20).

Geç Osmanlı döneminde ise ilk önce "millet bahçeleri" sonra "park" adı altında şehrin farklı yerlerinde, naturalist bahçe üslubunda kurulan mesire ve halk bahçeleri yer almıştır. Osmanlı döneminde başlayan modernleşme çalışmaları Cumhuriyet kurulduktan sonra da 
devam etmiş; yeşil alanlar imar planları ile oluşturulmaya başlanmıştır.

\subsection{Millet Bahçeleri}

Osmanlı İmparatorluğu'nda bilinçli olarak siyasi aktörler tarafından başlatılan ilk batılılaşma hareketlerinin XVIII. yüzyılın başlarından itibaren kendini gösterdiği bilinmektedir. Lale Devri olarak adlandırılan dönemde (1718-1730), her ne kadar büyük bir modernleşme hareketi olmasa da yine de ilk Batılı etkilerin Osmanlı toplumuna girmesi bakımından önemli görülmektedir. Özellikle Paris'te Türk elçiliğinin başlattı̆̆ Avrupa modasının, yeni stil ve tarzın yeni sosyal hayatın ilk nüveleri olarak görülmesi ve bunun bir süre sonra İstanbul'da da karşılık bulması, kültürel anlamda Avrupa entegrasyonunun ve yabancı kültürün ilk fakat etkileyici yansımasını göstermektedir (Kiraz 2018: 4).

Modernleşme ile birlikte yeni bir toplumsal yapılanmanın ortaya çıkması ve gündelik toplumsal pratiklerde ifadesini bulan bu farklılıkların mekanların sahiplenilmesine, mekanın üretim süreçlerine ve kullanımlarına yansıması kaçınılmaz olmuştur (Gürkaş 2004: 410). Osmanlı modernleşmesi sürecinde, kentleşme olgusunun mekansal boyutuna bakıldığında pek çok kentte, geleneksel kent dokusunun yanı başında, yeni kentsel kullanımlar ile yeni bir modern merkez gelişiminin gerçekleştiği görülmektedir (Selvi Ünlü 2012: 251). Bu süreçte kentin formu ve anlamı değişmeye başlamış ve devlet için kentsel mekan prestij ve imaj mücadelesinin görünür alanı olmuştur. Bu nedenle, kentte batıya referanslı park ve bahçelerin oluşturulması, kamusal ve estetik kaygılardan çok iktidarın zafer alanı olmuştur. Böylece başta İstanbul olmak üzere taşra kentlerinde de batılı yaşam biçimi gereği, batıdaki parkların küçük bir modeli olarak millet parkları ya da bahçeleri, kentin görünürlügü en yüksek düzeyde olan kent merkezinde ve genellikle hükümet konaklarının karşısına kurulmuştur. Böylece, kadınla erkeğin bir aradalığına eşdeyişle cinsiyet ayrımı olmadan bireyin sosyalleşmesine ortam yaratmasıyla, bu mekanlara görünürlük kazandırılarak kabul edilmesini kolaylaştırmak ve hızlandırmak amaçlanmıştır (Turgut Gültekin 2015: 10).

Tanzimat ve Islahat Fermanları ve arkasından Kanuni Esasi'nin ilan edilmesiyle önce "millet" ve "ümmet-tebaa" kavramları yeniden düzenlenmiş, ümmet ve millet bütünleştirilerek, hepsi 'millet' yapılmıştır. Tanzimat'tan önceki Osmanlı devlet düzeninde Müslümanlar ümmet-tebaa, Müslüman olmayan topluluklar ise millet olarak tanımlanmıştır. Millet Bahçeleri ise bu bütünlüğü simgeleyen bir kavramdır. Tanzimat sonrası yapılan düzenlemeler tüm devlet sathında yeni teşkilatların kurulmasını, halkın yaşam biçiminin dönüştürülmesini, sosyalleşme gibi kavramları beraberinde getirmiştir. Bu kapsamda hazırlanan Vilayet Nizamnamesi içinde yer alan bir konu da "Millet Bahçeleri"dir (Memlük 2017).

Avrupa'da yönetim biçimlerinin değiştiği dönemde ortaya çıkan park kavramının Osmanlı'da uygulanabilmesi amacıyla Sultan Abdülaziz döneminde halka açık, umumi bahçeler yapılmış ve bu bahçelere "Millet Bahçesi" adı verilmiştir (Memlük 2013). Millet Bahçeleri, Fransa'daki Halk Bahçelerinden esinlenilerek yapılmıştır. Millet Bahçeleriyle, kişilerin ve toplumun sosyalleştirilmesi ve kontrol edilmesi hedeflenmiştir (Memlük 2009: 75). Devletin denetimi yalnız mekana değil, kendi vatandaşlarının mekandaki davranışları üzerinde de uygulamak istediği görülmektedir. Bu denetlemenin ve dolayısıyla da devletin varlığının, prestij ve imajının bu mekanlar üzerinde etkisinin olmasının belirtilerinden biri de halkın kullanımına sunulan alanların isimleri üzerinden okunabilir. II. Meşrutiyet'e kadar bulunduğu mevkiinin isimleriyle anılan bağ, bahçe, mesire yerler ve korular park olarak "millet", 
"hürriyet" gibi ön adlar almaya başlamıştır (Gürkaş 2009: 178).

Osmanlı modernleşmesi bağlamında, kentsel düzenlemeler içindeki yeşil alanlar, bunların oluşturulması ve kullanılması toplumun üç kesimini etkilemiştir. Yeşil alan ve onu var eden değişim, Osmanlı bürokratik eliti, ticari burjuvazi ve bunların dışındaki kentli gruplar tarafından farklı anlamlandırılmış ve kullanılmıştır (Gürkaş 2009: 411). Modernizmin öngördüğü kentsel kamusal mekan niteliğindeki millet bahçelerinin toplumun her kesimi tarafından kolaylıkla kullanıldığı ve istenebilir olduğu söylenemez (Turgut Gültekin 2015: 11).

İstanbul'daki ilk millet bahçesi, Taksim Millet Bahçesidir. 1866 yılında Sultan Abdülaziz döneminde açılmıştır. İlk millet bahçesinden 3 yıl sonra, Üsküdar'da Sarıkaya Millet Bahçesi (1868-1869) oluşturulmuştur. İstanbul'da açılan üçüncü millet bahçesi, Sultan Ahmet Meydanı'na yaptırılan (1871-1872) Sultan Ahmet Millet Bahçesidir. Daha sonra Tepebaşı Millet Bahçesi ve Kısıklı Millet Bahçesi tesis edilmiştir (Memlük 2009; Gürbüz 2009: 185). İstanbul dışında Adana, Ankara, Aydın, Bursa, Edirne, Erzurum, Kars, Kayseri, Konya, Mersin, Sinop ve Sivas'ta da Millet Bahçesi yapılmıştır (Memlük 2017).

Sultan Ahmet Millet Bahçesi daha sonra Yeni Millet Parkı olarak adlandırılır. Park büyük köşk bahçesi karakteri taşır; ortasında kafe olarak kullanılan tek katlı, kiremit çatılı, verandalı bir yapı bulunur (Fotoğraf 2). Parkın uygun yerlerine kubbe formunda pergolalar yerleştirilmiş, parktaki çiçek tarhlarını ve ağaçlarını koruma amaçlı ahşap malzemeden yapılmış sınır elemanı çevrelemiştir. Tek giriş kapısı olan parkın iç tarafına, Ligustrum sp. (kurtbağrı) ve Pseudoacacia sp. (yalancı akasya) türleri lineer düzende dikilmiştir (Nuhoğlu vd. 2016: 9).
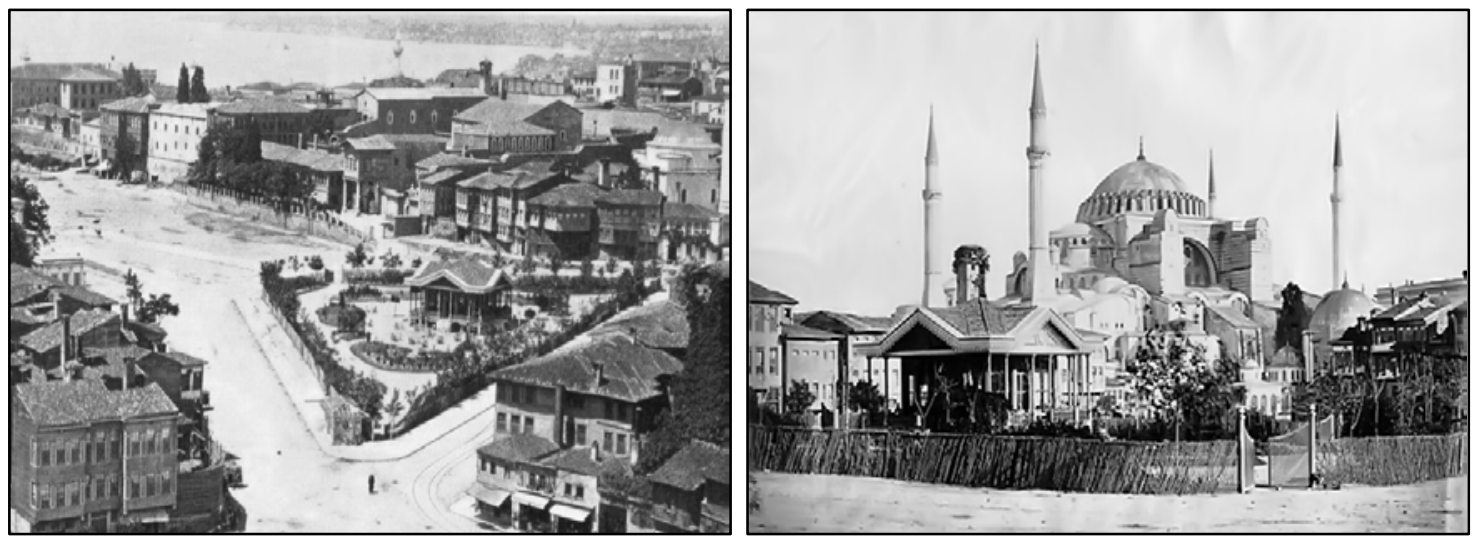

Fotoğraf 2. Sultan Ahmet Millet Bahçesi (Yeni Millet Parkı) (Eski İstanbul Fotoğrafları Arşivi)

Millet Bahçelerinin içine yerine ve büyüklügüne bağlı olarak, müzik köşkleri, lokantalar, gazino, dans ve oyun salonları, konser, sinema ve tiyatro salonu gibi yapılara da yer verilmiştir. Ankara Millet Bahçesi, akasya ağaçları, ortasındaki havuzu ve ahşap sinema binası ile Ankaralıların çeşitli kutlamalar (Sakarya Meydan Savaşı zaferi, ilk İşçi Bayramı ve bando dinletileri) için yoğun olarak kullandıkları, Ankara'nın ilk çiçekçisine ev sahipliği yapan bahçe içerisinde Atatürk'ün de sıklıkla gittiği bir lokanta ve çay bahçesi bulunmaktadır (Fotoğraf 3) (Memlük 2009: 75). Törenlerin izlenme yeri, milletvekillerinin ve bürokratların dinlenme mekanı olan Millet Bahçesi'nde film gösterimleri, localı sinema binasında gerçekleştirilmeye başlanmış, bina tiyatro temsillerine ve Büyük Orkestra'nın Ankara'daki ilk konserine de ev sahipliği yapmıştır (Bayraktar 2013: 68).

TBMM'nin karşısında yer alan Millet Bahçesi'nin Ankara'nın modernleşme serüveninde ve 
eğlence kültüründe özel bir yeri olmuştur. Kurtuluş Savaşı'nın ilk döneminde Azm-i Milli örgütlenmesinin oyunlar sahnelediği Millet Bahçesi'nde; Ahmet Hilmi Bey, Ankara'nın ilk tiyatro ve sinema salonunu açmıştır. Milli Mücadele dönemi Ankara'sında yazarların buluştukları ve edebi sohbetler yaptıkları bir yerdir (Tonga 2014: 198).

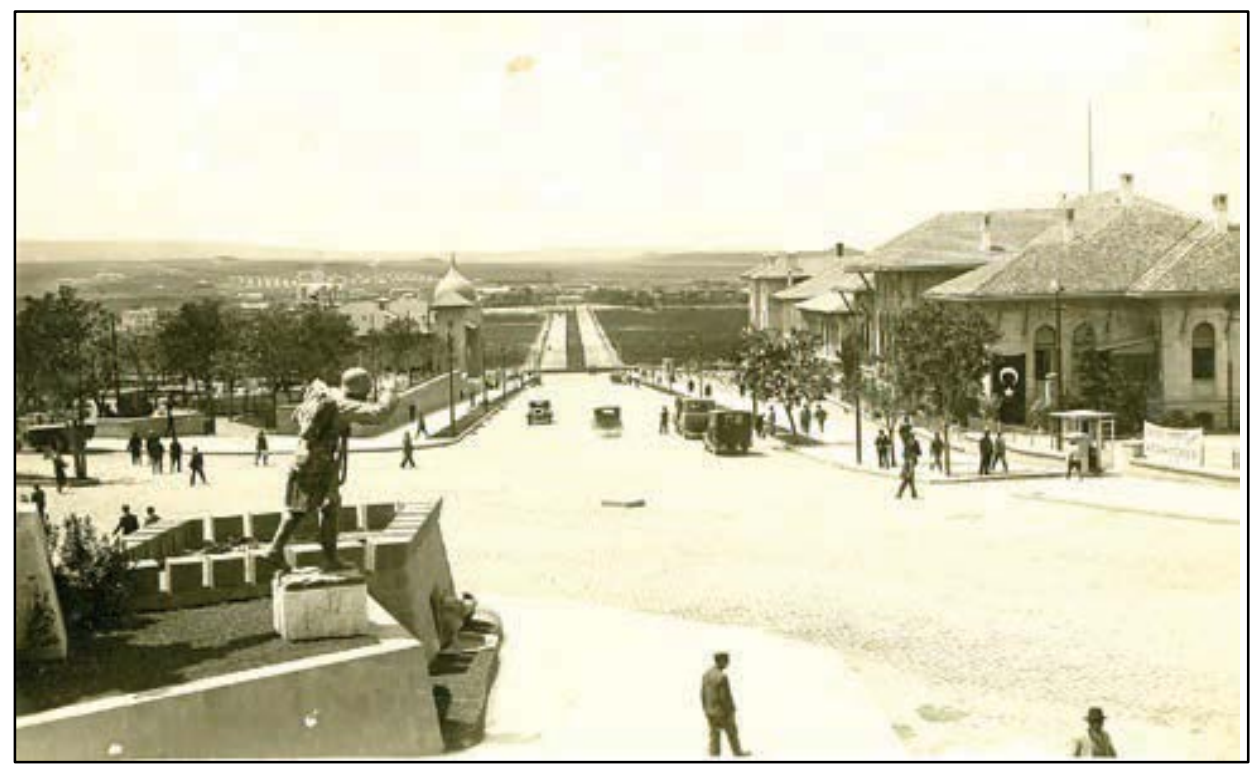

Fotoğraf 3. Ankara Millet Bahçesi (1932) (VEKAM Arşivi)

Millet Bahçeleri, kent formunda ve halkında etki oluşturduğu gibi dönemin edebi eserlerinde de etkileri görülmektedir. Recaizade Mahmut Ekrem'in Araba Sevdası adlı romanında Çamlıca Millet Bahçesi'nin tasvirleri yer almaktadır. Ekrem, Çamlıca Millet Bahçesi tasviriyle romana başlamış ve bahçeyi kuşbakışı görüyormuş gibi anlatmıştır. Romanda bahçenin ağaçlık ve şose yolu, bahçe duvarı ve üzerindeki tellere kadar ayrıntılı bir aktarımla bahçe anlatılmaktadır (Fotoğraf 4) (Akgül 2016: 513).

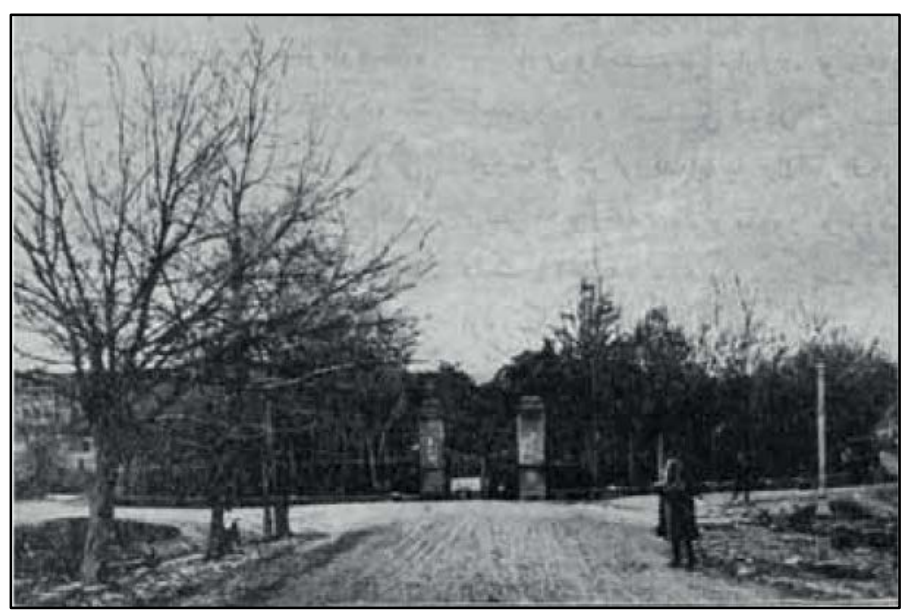

Fotoğraf 4. Araba Sevdası romanındaki Çamlıca Millet Bahçesi fotoğrafı (Akgül 2016: 514)

Ankara Millet Bahçesi de Yakup Kadri Karaosmanoğlu'nun hatıralarında dönemin yazar ve aydınlarının sohbet ettikleri önemli bir yer olarak anlatılmıştır (Karaosmanoğlu, 1999). 


\section{OSMANLI DÖNEMINDE KONYA}

Çok katmanlı ve kültürlü bir özelliğe sahip olan Konya'da, tarihin farklı dönemlerinde önemli medeniyetlerin katkısıyla oluşmuş bir yerleşim dokusu mevcuttur. Kent dokusundaki sivil mimari örnekleri ve kamusal alanlar, tarihi ve kültürel değer taşıyan bir kent hafızası oluşturmaktadır.

Konya'nın yerleşim tarihine bakıldığında Konya ve çevresinin M.Ö. 8000-6000 yıllarından itibaren yerleşim yeri olduğu bilinmektedir. Hititler, Frikyalılar, Lidyalılar, Kimmerler, Kapadokya Krallığı, Bergama Krallığı ve Romalılar gibi tarihte önemli bir yere sahip medeniyetler yerleşim merkezi olarak Konya'yı tercih etmişlerdir. Selçuklular Dönemi'nde başkent olması (1097-1308) Konya'nın her yönden gelişmiş bir yerleşim olmasını sağlamıştır. Bu özellik Karamanoğulları Beyliği ve Osmanlılar Dönemi'nde de devam etmiştir (Çelik 2015: 15). Anadolu Selçuklu ve Karaman Beyliği'ne başkentlik yapmış olan Konya, Osmanlılar döneminde de şehzadelerin ve Karaman beylerbeylerinin ikametine sahne olmuştur. Böylelikle başkentlik konumu Osmanlı egemenliğinde eyalet çapında da olsa devam etmiştir (Yörük 2017: 355).

Konya'nın yerleşim karakterini belirleyen özellikler Selçuklular Dönemine aittir. Ayrıca Konya'nın açık-yeşil alan sisteminin de Selçuklular Döneminde oluştuğunu söylemek mümkündür. Doğunun imar sistemi olan "şehir çevresindeki bahçe kuşakları" Selçuklu şehirlerinde de uygulanmıştır. Konya ve diğer Selçuklu şehirleri "bahçe-şehir" kavramına uygun olarak imar edilmiştir. Konya, çevresinde yer alan bağlar, bahçeler, bostanlar, sebzelikler ve otlakların yanı sıra şehrin içine dağılmış çok sayıda bahçesiyle yeşil bir yerleşimdir (Çelik 2016: 31). Şehrin ilk merkezi olan İç Kale ve çevresi, özellikle Osmanlı hakimiyeti boyunca yerleşim yeri olarak kullanılmaya devam edilmiş; Dış Kale surlarının dişında yeni mahalleler kurulmuş ve hatta sur dişındaki alanlarda çoğunlukla bağ ve bahçeler yer almıştır. Geniş ve düz bozkırdaki şehrin etrafını bağ ve bahçeler çevrelemektedir. Konya, ikamet bölgesi, ticaret bölgesi ve en diştaki bahçelik alanlar olarak 3 bölümden oluşmaktadır. Osmanlı döneminde, şehirde yaşayan insanların büyük bir kısmının, şehrin kuzey cephesi hariç üç tarafını çeviren bölgelerden birinde az veya çok bir parça bağ veya bahçesi bulunurdu. Kentin batı ve güney yönünde bulunan Meram, Dere, Yaka, Köyceğiz, Karahöyük, Ayamanas ve Karaaslan bölgeleri surlar arasında geniş yeşil alanlar uzanmaktadır (Muşmal 2016: 135).

Hem Selçuklular hem de Osmanlılar Anadolu'da oluşturdukları yerleşimlerde kültürlerini de yaşatmışlardır. Bu kültürel özellikler arasında 'bağ ve bahçe kültürü' de yer almaktadır. Konya'da Selçuklu döneminde bağ (Meram Bağları, Musalla Bağları ve Sille Bağları) (Fotoğraf 5) ve bahçelerden (Selçuklu Sarayı Bahçesi, Dede Bahçesi ve gül bahçeleri) (Fotoğraf 6) oluşan "yeşil alan sistemi" Osmanlı döneminde de aynı özelliğini devam ettirmiştir. Hatta Osmanlı döneminde mor ve siyah renkte yetiştirilen özel gül bahçelerine de yer verilmiş; yol ve parklara dikilecek ağaç ihtiyacını karşılamak için fidanlık kurulmuştur. 1920'lerde ise Konya'ya ilk defa yıldız çiçeği (Dahlia sp.) getirilmiş ve her rengi yetiştirilmiş; Dede Bahçesi'nde ise "Yıldız Çiçeği Yarışması" yapılmıştır (Çelik 2016: 36). 

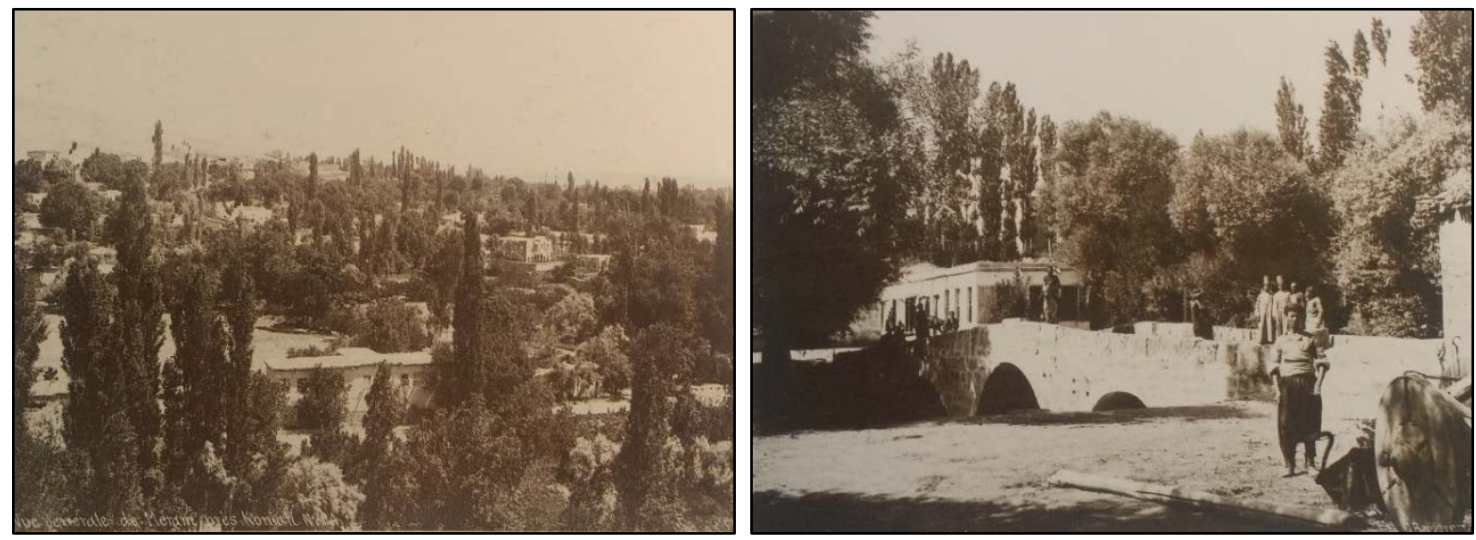

Fotoğraf 5. Meram Bağları (Karpuz 1996 98-99)
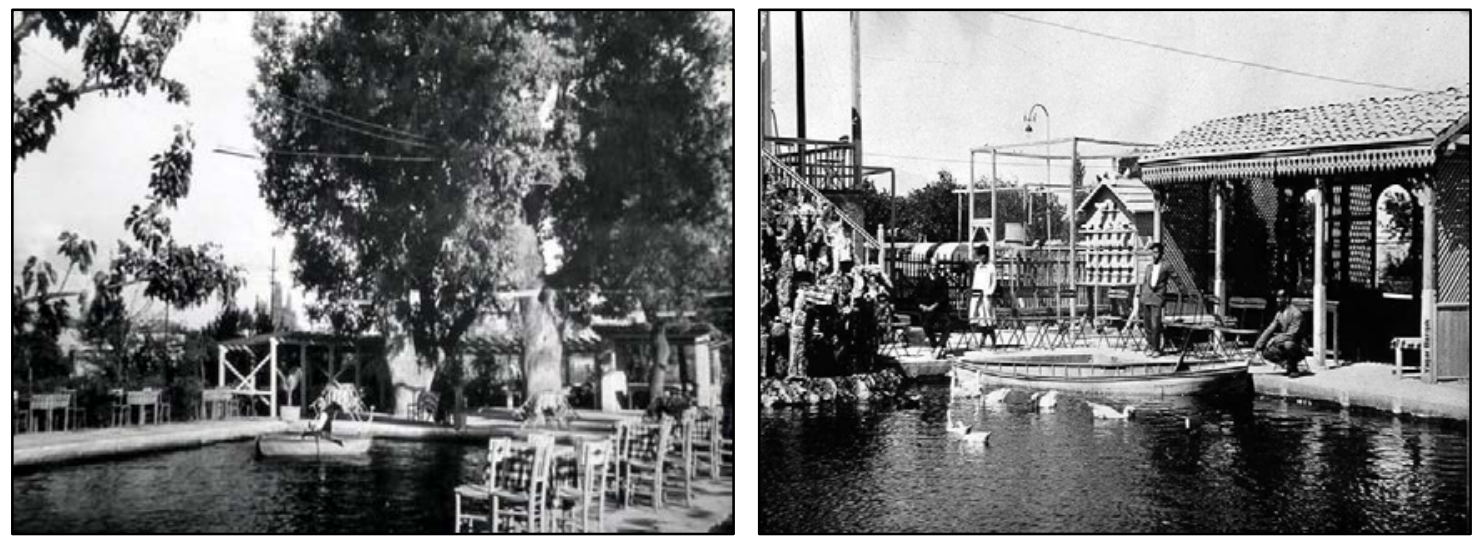

Fotoğraf 6. Dede Bahçesi (Yaşar Barışık’ın fotoğraf arşivi)

Osmanlı Döneminde Konya, mesire yerleri, bahçeleri, bağları, bağ evleri, han, hamam, çarşı ve pazar yerleri ile dönemin en gelişmiş şehirlerinden biridir (Topçu 2011: 1060). Şer'iyye Sicil kayıtlarından Konya'nın çevresindeki bağların kent halkı tarafından yazlık yerleşme olarak kullanıldığ 1 anlaşılmaktadır. Nigaristan ise Alaeddin Tepesi ile Kavele ve Meram arasındaki alanda muhteşem köşkler, saraylar, kervansaraylar, mesire yerleri, meyve bahçeleri ve üzüm bağlarının yer aldığını belirtmiştir (aktaran Aktaş Yasa 1998: 67).

Osmanlı Devleti'nin haberleşme, ticaret, askeri sefer, hac seferi ve devlet memurlarının görev yerlerine güvenle ulaşmaları amacıyla; belli güzergâhlar üzerinde menziller ve konaklama yerleri tesis ettikleri bilinmektedir. Bu bağlamda Osmanlı döneminde Konya, İstanbul'dan başlayarak Anadolu ve kutsal topraklara doğru devam eden ve Osmanlılar zamanında "sağ kol güzergahı" olarak adlandırılan hat üzerinde yer almıştır (Çaycı 2016: 115). Eskiçağlardan itibaren Anadolu'nun en işlek ana yol güzergahlarından biri olan sağ kol üzerinde bulunması nedeniyle ticaret kervanlarının, orduların, posta ulaklarının, hac kervanlarının uğrak yeri olmuştur. Konya'nın üzerinde bulunduğu sağ kol, özellikle Şam ve Kahire'nin alınmasından sonra ticaret yollarının dışında, hac yolu ve ordu yolu olarak da kullanılmıştır. Üsküdar'dan başlayan bu yol Gebze-Dil İskelesi veya İzmit üzerinden, İznikYenişehir-Bozöyük-Eskişehir-Seyitgazi-Hüsrev Paşa Hanı-Akşehir-Ilgın-Konya-KarapınarEreğli-Adana ve Antakya'ya ulaşmakta, Antakya'dan sonra bir kol Halep'e, bir diğer kol da Şam'dan Hicaz ve Mısır'a ulaşmakta idi (Yörük 2018: 357).

Stratejik bir güzergah üzerinde bulunduğu için Konya, yerli (Abdülkadir Çelebi, Evliya 
Çelebi, Katip Çelebi, Ahmet Tevfik, Şemseddin Sami, İbn Said, Mehmet İbn Ömerü'l-Aşk, Bedrü'd-din İbn Raziyyi'd-din el-Gazzi, Kudbüddin Mekki, Abdurrahman Gubari, Abdurrahman Hibri, Amcazade Ali b. Şaban, Nabi, Bahri, eş-Şeyh el-Hac İbrahim, Mehmed Edib) ve yabanc1 (Paul Lucas, Clement Huart, Regis Delbeuf, Charles Textier, Léon de Laborde, Gertrude Bell) araştırmacı, fotoğrafçı, gezgin, resmi görevli ve sanatçıların özellikle ziyaret ettiği, uğradığı ve hatta belirli bir süre konakladığı bir şehirdir (aktaran Çaycı 2006: 116-130). Konya'ya farklı zamanlarda ve amaçlarla gelen ziyaretçilerin hepsi eserlerinde ve konuşmalarında Konya'nın bağ ve bahçelerinin kusursuz güzelliğinden bahsetmiştir.

Katip Çelebi, Cihannüma isimli eserinde Konya hakkında bilgi verirken "Konya batı ucundaki iki çatal dağın eteklerinde, düz yerde, akarsulu, bağlı, bahçeli bir şehirdir. Güney tarafında, o dağların eteklerinde Meram bahçe ve mesireleri bulunur. Dağdan şehre ve Meram'a akan ırmakları, şehrin tarla ve bahçelerini suladıktan sonra ova tarafına geçerek bir göl oluşturur ve o göl dağları ihata eder. Havası mutedil olan şehri bağlarının çoğu dağ tarafındadır" şeklinde açıklama yapmaktadır (aktaran Muşmal 2016: 134).

Clement Huart, kenti çölün ortasında bir vahaya benzetmiş, çevresinde bulunan dağlardan gelen dereler ile Meram Deresi'nin Konya'ya hayat verdiğini söylemiştir. 1901 yılında Konya'ya gelen Regis Delbeuf ise özellikle Meram bahçelerinin güzelliğini uzun uzun eserinde anlatmıştır (aktaran Muşmal 2016: 134).

Günümüzde sanat eseri olma özelliği taşıyan ancak Osmanlı döneminin resmi kayıt ve kitap resimleme yöntemi olan minyatür ve gravürlerde de Konya ve çevresi bağ ve bahçelerle çevrili yeşil bir kent olarak tasvir edilmiştir. Matrakçı Nasuh'un XVI. yüzyıla ait Konya minyatüründe (Fotoğraf 7) kentin içinde ve dişında yer alan bahçelerle birlikte bu bahçeleri sulamak için kullanılan Meram Deresi tasvir edilmiştir. Léon de Laborde, 1826 yılında Konya'yı gezmiş ve kentin genel görünümü hakkında bilgi veren Konya gravüründe ise (Fotoğraf 8) dış surlar ile sur kapılarına ait kalıntılar, cami, han, hamam, konutlar ve sokaklar ile kentin görüntüsü çizilmiştir. Ayrıca kentin çevresinde yer alan bahçeler de bu gravürde görülmektedir. 


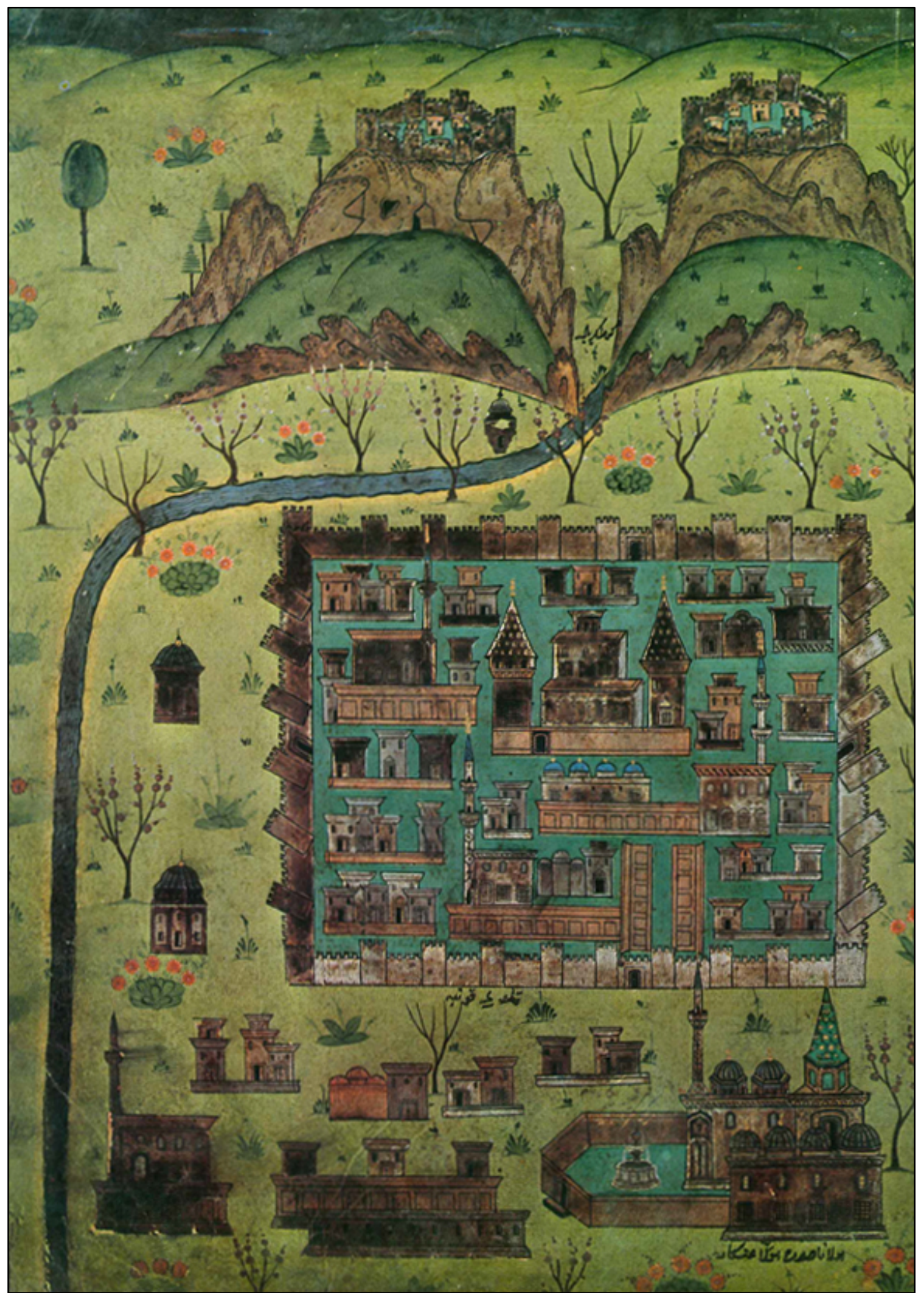

Fotoğraf 7. Matrakçı Nasuh'un XVI. yüzyıl Konya minyatürü (Konya Büyükşehir Belediyesi Eski Konya Fotoğrafları Arşivi) 


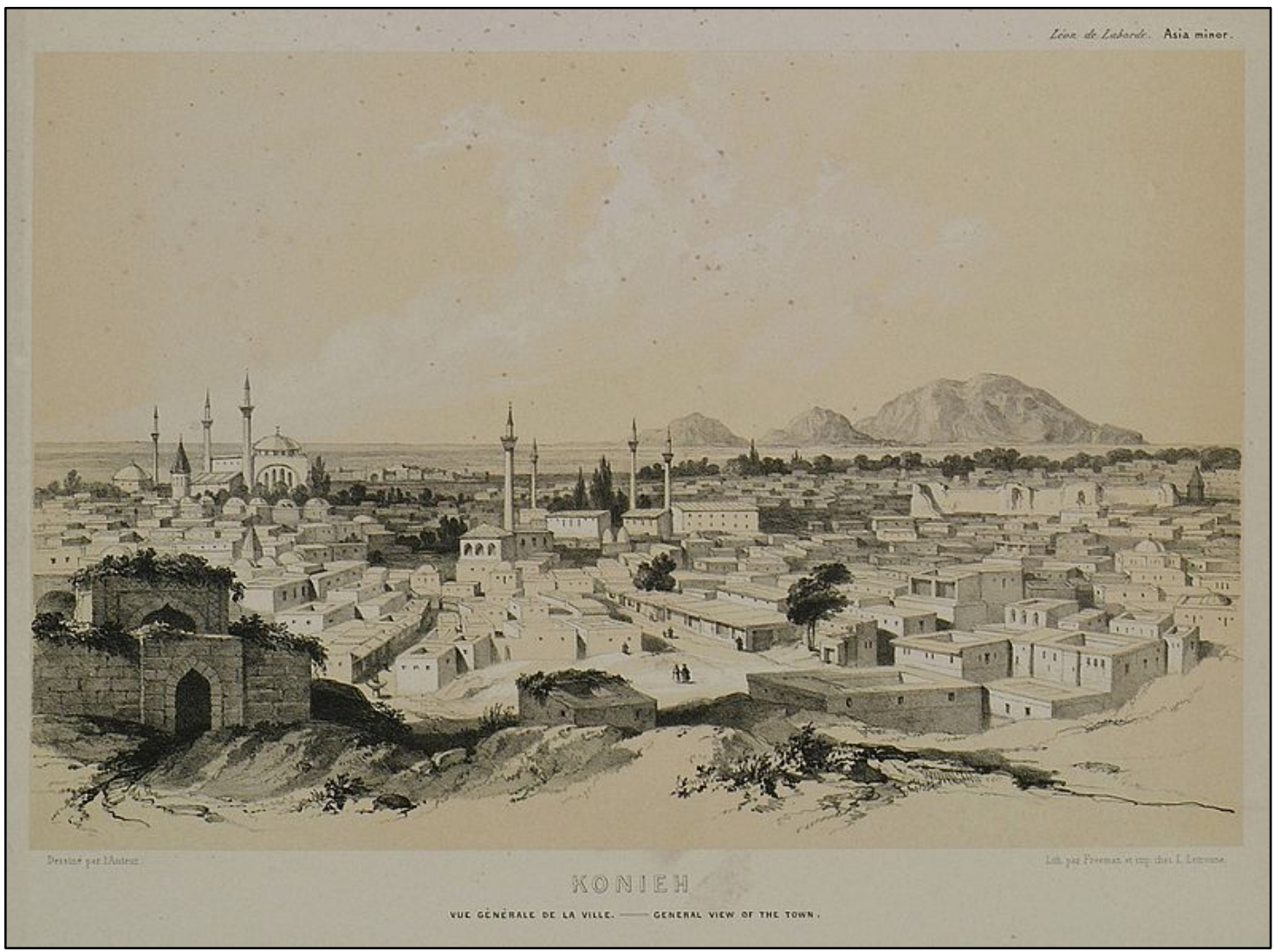

Fotoğraf 8. Léon de Laborde'nin 1826 yılına ait Konya gravürü (Konya Büyükşehir Belediyesi Eski Konya Fotoğrafları Arşivi)

Günümüzde olduğu gibi XVII. yüzyıldan itibaren köylerden kentlere doğru artan göçler sonucunda İstanbul, Bursa, Edirne ve Konya'da nüfus artmış, bunun sonucunda gecekondu bölgelerine benzeyen, inşaat kurallarına uyulmadan yapılan binalar kentlerin içini ve etrafındaki bağlık ve bahçelik alanları kaplamaya başlamıştır (Özcan 2017: 103).

XX. yüzyılın ilk yarısına kadar Konya, merkezde yoğun olmayan kent yerleşimi ve merkez dışında yerleşimi saran bağ, bahçe ve tarlalarıyla bahçe-şehir özelliğini korumuştur (Oktaç 2003: 275). Ancak imar planları doğrultusunda yapılan uygulamalar Konya'nın kendine özgü yerleşim karakterini ve bağlarını-bahçelerini yok etmiştir (Çelik 2016: 35). Cumhuriyetin ilanından sonra birçok şehirde olduğu gibi Konya'da da 1933 yılındaki ilk etütlerle birlikte imar faaliyetleri başlamış ancak önerilen projeler uygulama imkanı bulamamıştır. Konya'nın ilk imar planı 1945 yılında yapılmış olmasına rağmen 1960'lı yıllara kadar Konya'da değişim yaşanmamıştır (Topçu 2011: 1058).

Geç Osmanlı döneminde başlayan modernleşme çabaları Cumhuriyet döneminde de süreklilik göstererek devam etmiştir. Doğal yeşil alanlarla iç içe olan Konya'da Geç Osmanlı dönemi (Millet Bahçesi ve Halk Bahçesi) ve erken Cumhuriyet döneminde inşa edilen parklar (Fahrettin Paşa Parkı, Kayalı Park, Alaeddin Tepesi üzerindeki ve eteğindeki parklar) yeşil alan sistemine dahil edilmiştir. Ancak bu parkların büyük bir kısmı günümüze ulaşamamıştır. 


\section{KONYA MİLLET BAHÇESI}

II. Abdülhamit döneminde başlayan yeşil alanların batı tarzında düzenlenmesi sürecinde Konya'da da Millet Bahçesi bu düşünceden etkilenerek yapılmıştır. Batılılaşma süreciyle başta İstanbul olmak üzere Anadolu'da birçok şehirde oluşturulan Millet Bahçesi, Konya'da 1912'de halkın kullanımına sunulmuştur. Ancak yalnızca bayramlarda halkın kullanıma açılmıştır (Odabaşı 1998: 95).

Millet Bahçesi'nin günümüzdeki yeri, Konya Lisesi (Gazi Lisesi) ve Anıt Meydanı'nın karşısında; Konya Devlet Tiyatrosu, Meram Kız Meslek Lisesi ve Konya Yazma Eserler Bölge Müdürlüğü'nün bulunduğu alandır (Fotoğraf 9). Bahçenin tasarım özelliklerine yönelik detaylı bir bilgi yoktur. Ancak yazılı ve görsel kaynaklara göre sade ve natüralistik bir bahçe olduğu anlaşılmakta; bu yönüyle Osmanlı bahçe özelliklerini yansıtmaktadır. Ancak içinde yer alan kullanımlar, batı etkisini ortaya koymaktadır.

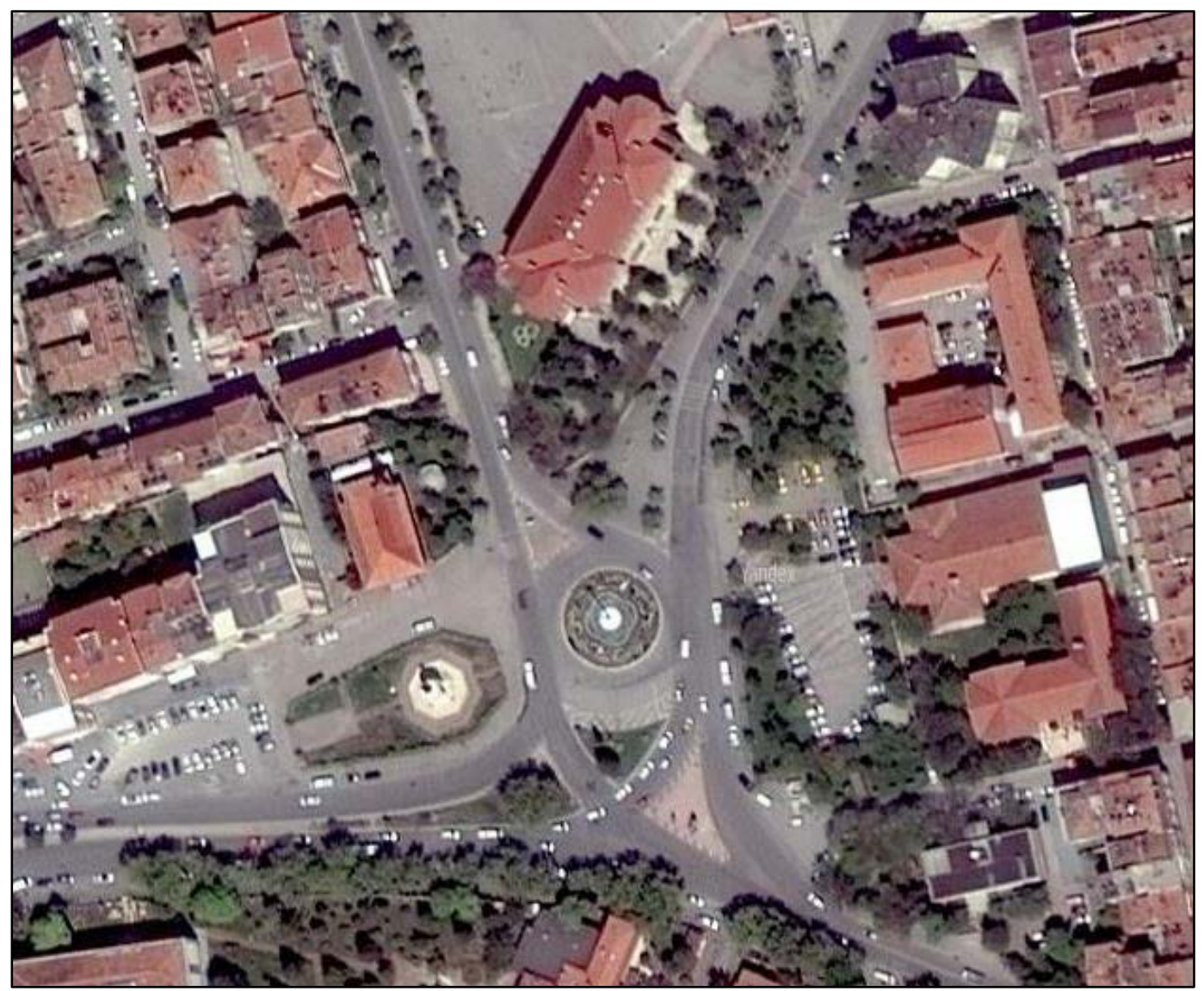

Fotoğraf 9. Millet Bahçesi'nin günümüzdeki yeri

1912 yılından önce Konya'daki ilk park, Konya Lisesi'nin olduğu yerde bulunan "Halk Bahçesi"dir. Aynı zamanda Belediye Bahçesi olarak anılan bu parkın yerine 1912 yılında Darü'lmuallimin (Mualim Mektebi, günümüzdeki Gazi Lisesi-Konya Lisesi) yaptırılınca, bahçenin karşısındaki alana da Millet Bahçesi (Fotoğraf 10) yaptırılmıştır (Odabaşı 1998: 95; Doğan 2015: 393). 


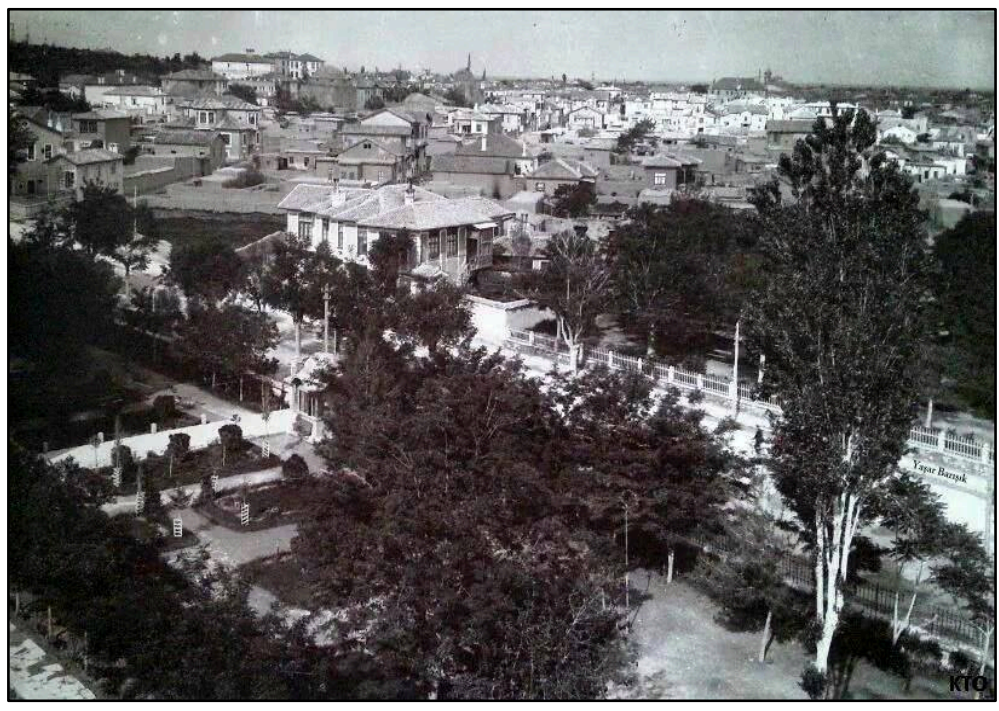

Fotoğraf 10. Gazi Lisesi'nin bahçesi ve karşısında Millet Bahçesi (Tevfik Ataberk'in fotoğraf arşivi)

Millet Bahçesi'nin yapıldı̆̆ı dönemde duvarla çevrili, geniş ve yeşil (Fotoğraf 11) bir park olduğu ve ayrıca muhteşem bir kapısı olduğu belirtilmiştir (Fotoğraf 13). Konya Millet Bahçesine kesme taştan yapılmış, sütunlu, kemerli bir taçkapıdan girilmektedir. Taçkapı üzerinde kitabe yoktur. Bahçe içerisinde tenis kortu, dans pisti, açık hava konser sahnesi, köşkler ve kameriyeler vardır Doğan 2015: 394).

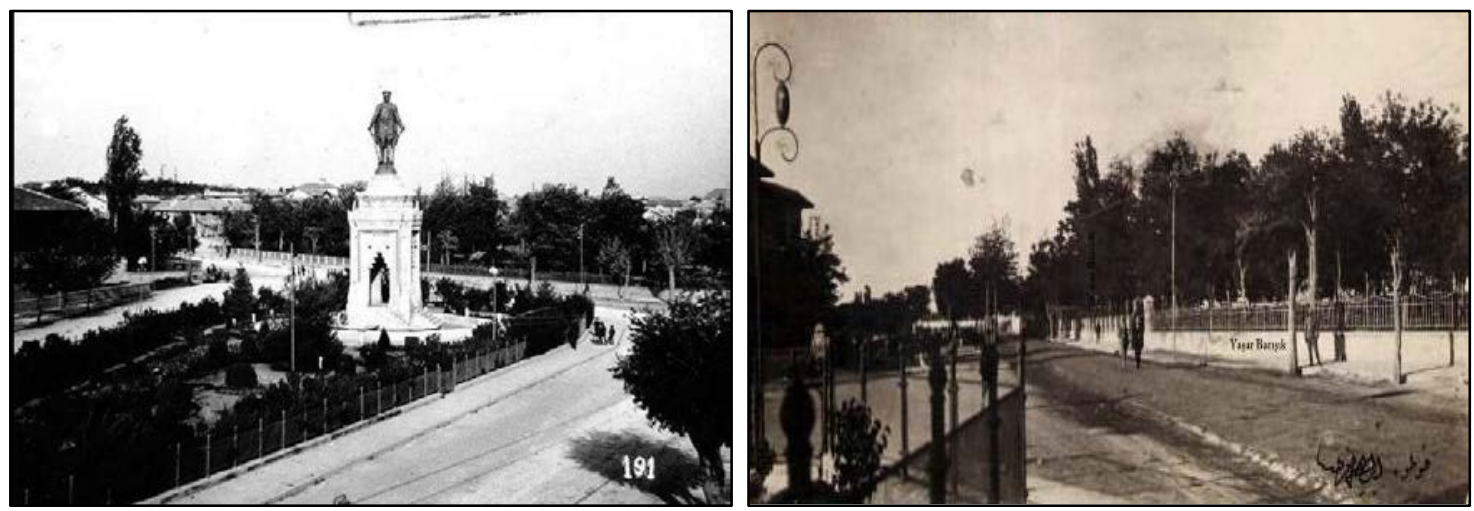

Fotoğraf 11. Anıt Meydanı'nın karşısında Millet Bahçesi (Yaşar Barışık'ın fotoğraf arşivi)

1919-1923 yıllarında Belediye başkanı olduğu dönemde Mehmet Muhlis Koner, Iskarta adlı İtalyan mimar-mühendise Konya'nın imar planını yaptırmıştır. Millet Bahçesi ile İstasyon Caddesi ve Karaman Caddesi bu plana göre düzenlenmiştir (Doğan 2018).

Yapılan müdahalelerle Millet Bahçesi, önce küçültülmüş daha sonra da tamamen yok olmuştur. Üzerine yapılan Konya Devlet Tiyatrosu ${ }^{1}$ binasından sonra küçülen park, Konya Yazma Eserler Kütüphanesi'nin inşasından sonra tamamen ortadan kalkmıştır (Fotoğraf 12).

\footnotetext{
${ }^{1} 1946$ yılında Halkevi olarak yapılmış olan bina, Halkevleri kapatıldıktan sonra bir süre sinema salonu olarak faaliyet göstermiş̧, daha sonra da İl Halk Kütüphanesi olarak kullanılmış bir mekandır. Günümüzde ise Konya Devlet Tiyatrosu olarak hizmet vermektedir.
} 


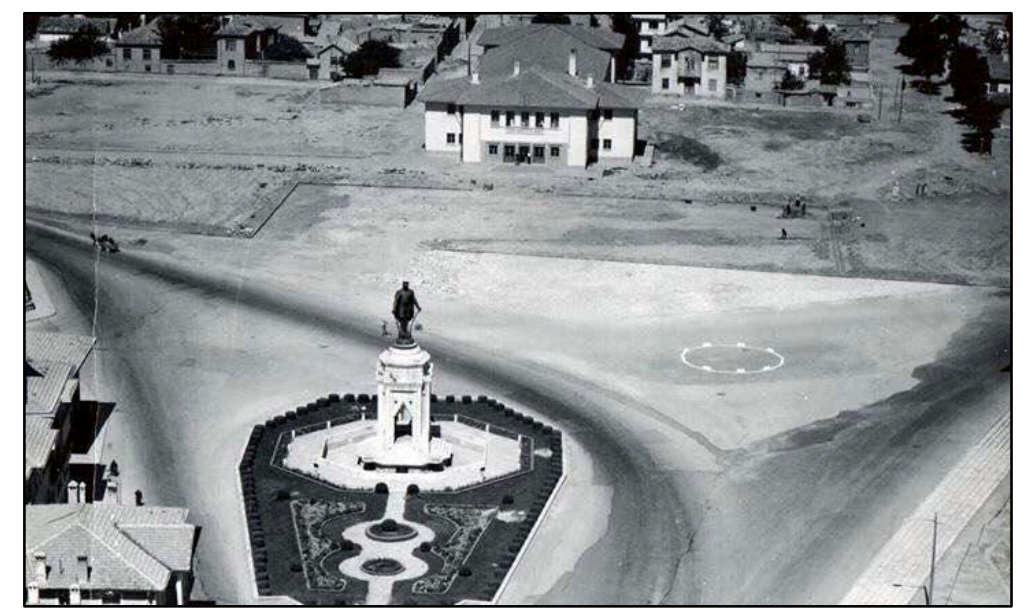

Fotoğraf 12. Millet Bahçesi yerine yapılan Konya Devlet Tiyatrosu (Tevfik Ataberk'in fotoğraf arşivi)

Millet Bahçesi'nin kapısı ise önce Yüksek İslam Enstitüsü daha sonra da İmam Hatip Lisesi olan okulun bahçesinin ana giriş kapısı (Fotoğraf 13) olarak bahçe duvarına monte edilmiştir (Doğan 2015: 392). Millet Bahçesi kapısı, Konya Kültür Varlıklarını Koruma Bölge Kurulu tarafından 2863 sayılı yasada belirtilen özellikleri taşıması nedeniyle 05.02.2013 tarihinde 2 . grup yap $1^{2}$ olarak tescil edilmiştir (KKVKBK 2013).
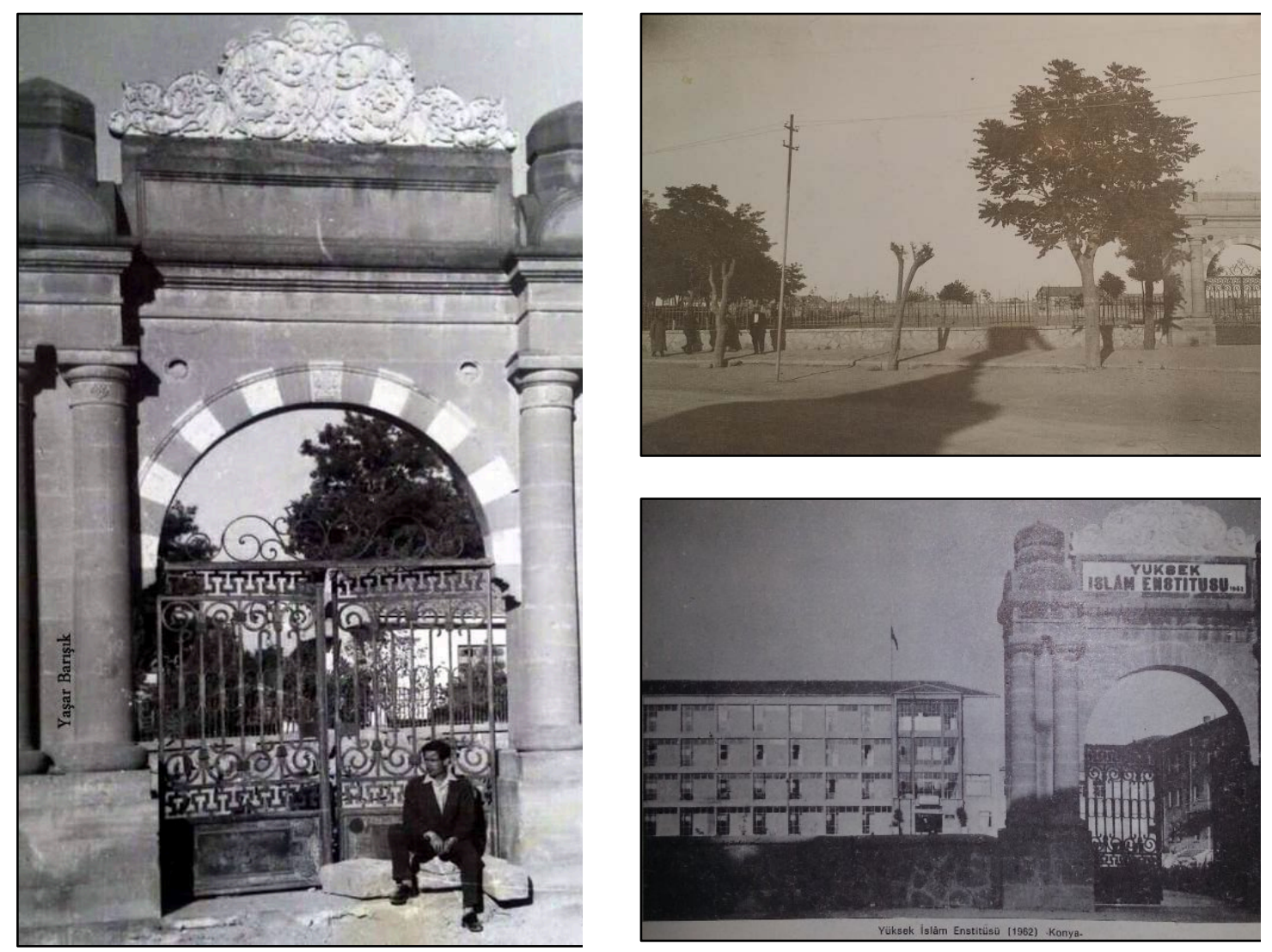

Fotoğraf 13. Millet Bahçesi'nin taçkapısı (Yaşar Barışık'ın fotoğraf arşivi)

2. Grup Yapılar, kent ve çevre kimliğine katkıda bulunan kültür varlığı niteliğindeki yöresel yaşam biçimini yansitan yapilardır. 


\section{TARTIŞMA VE SONUÇ}

Mekan üzerinde ısrarla duran ve mekanı toplumsal ilişkiler bağlamında çözümlemeye çalışan XX. yüzyılın önemli filozoflarından Henri Lefebvre "Mekanın Üretimi" adlı eserinde, zamanın olduğu gibi mekanın da bir tarihi olduğunu, toplumların mekanları değişim sürecine tabii tuttuklarından bahsetmekte ve dolayısıyla da aktörlerin değişmesi ile mekanların tarihinin tekrar tekrar yazılmasına ihtiyaç olduğundan söz etmektedir. Bu durumun gerçekleşmesinde, iktidarların zihnindeki esas unsur, kenti eskiden arındırarak modernleştirme ve yeniden yaparak güzelleştirme fikridir. Modernleşme pratiği içinde yer alan yıkmak ve kendi ideolojisi çerçevesinde yeniden yapmak ya da kurgulamak, birbiri ile başlangıç ve sonuç ilişkisi içinde olan kavramlar olup, eski veya geleneksel olan her şeyin hızlıca tüketilmesi ve yerine yenisinin koyulması düşüncesine dayanmaktadır (İgüs-İsmailoğlu 2016: 115-116). Osmanlı İmparatorluğu'nda kent planlama doğrultusunda yapılaşmış çevreye müdahale edilmesi siyasi iktidarın isteğiyle XVIII. yüzyılda başlamıştır. Bu başlangıç, Tanzimat Fermanı ile gerçekleşen politik, bürokratik ve toplumsal modernleşme ile eş zamanlı olmuştur. Merkez-çevre etkili olduğu için öncelikle İstanbul'da başlamış daha sonra diğer kentlere doğru yayılmıştır. Batılılaşma sürecinde Osmanlı kentleri yeniden üretim mekanı haline gelmiş; kentsel mekandaki değişimle toplumsal değişim karşılıklı olarak birbirini etkilemiştir. Modernleşme ile birlikte yaşanan toplumsal değişim, yeni yeşil alanların işlevine, formuna, benimsenmesine ve kullanılmasına da yansımıştır.

Önce Osmanlı döneminde başlatılan batılılaşma; arkasından gelen Cumhuriyet döneminde gerçekleştirilen modernleşme süreci yeşil alanların değişimi, dönüşümü ve hatta yok olmasıyla sonuçlanmıştır. Batılılaşma ve modernleşmenin adından gelen ve tüm Dünya ile birlikte Türkiye'yi de etkisi altına alan küreselleşme sürecinde ise yapılan standartlaştırıcı uygulamalar, yeşil alanların kimliğini ve dönemsel özelliklerini yok etmiştir. Ayrıca tarihi arasta, çarşı, kahvehane, cami gibi kamusal alanlara göre bahçe ve parklar, müdahale edilerek değiştirilmesi daha kolay olduğu için günümüzde Türk Bahçesi mevcut değildir. Bu nedenlerden dolayı çok köklü bir tarih ve kültürel özelliklere sahip, Selçuklu ve Osmanlı dönemlerinin özelliklerini taşıyan Türk Bahçesi, özgün haliyle varlığını sürdürememiştir. İstanbul ve Anadolu'da diğer kentlerdeki Millet Bahçelerinin de kültürel peyzaj öğesi olarak korunup geleceğe aktarılması mümkün olamamıştır.

İşlev ve form açısından yeni bir yeşil alan tarzı olan Millet Bahçeleri, Osmanlı dönemi boyunca ve Cumhuriyetten sonra varlığını devam ettirdiği sürede toplum yaşamında önemli bir yere sahip olmuştur. Ancak Cumhuriyetten sonra da devam eden modernleşme çalışmaları ile köklü mekansal dönüşümler gerçekleştirilmiş; geleneksel Osmanlı yerleşmelerinin özgün karakteri yok olmuştur. Geleneksel kent dokusu ve Millet Bahçeleri de zaman içinde dönüşmüş veya tamamen yok olurken Osmanlı dönemine ait kent hafızası ve kent kimliği de yok olmuştur.

Batılılaşmanın etkisiyle kent mekanında ve toplum yaşamında gerçekleştirilen değişimler, Anadolu kenti olan Konya'da da görülmektedir. Konya kent halkına modern mekanlar ve modern bir yaşam sunmak ve bu moderniteye alıştırmak için çeşitli uygulamalar yapılmıştır. Konya Millet Bahçesi, taçkapısı ve batı tarzındaki düzenlemesiyle batılılaşma çalışmaları kapsamında kentte, kent halkında ve toplumsal yaşamda değişiklik yaratılmasında etkili olmuş kamusal alanlardan biridir. Millet Bahçesi'nde daha önce Konya'daki kamuya açık bahçelerde yer almayan tenis kortu, dans pisti ve açı hava konser sahnesi, kent halkının eğlence ve rekreasyon anlayışının değiştiğini göstermektedir. Konya Millet Bahçesi'nin oluşumunda 
merkez iktidarın etkisi olsa da kullanımında kent halkının tercihleri etkin olmuştur. Günümüze ulaşamamış olan Millet Bahçesi, Konya kent hafızası ve kent kimliği açısından kaybedilmiş kültürel bir değerdir. Millet Bahçesi, Konya tarihini anlatan yazılı kaynaklar, fotoğraflar ve çok az sayıdaki yaşlı bireylerin hafızalarında kalan mekanlardan biridir.

\section{SUMMARY}

The westernization movement in Ottoman Empire from Tanzimat Edict to the Republic of Turkey, which led to the modernization process that took place between 1839 and 1923, has manifested itself in all fields from state administration to education, politics, social, culture, economy and settlements. During the westernization process of the Ottoman Empire, in all fields, western standards have begun to take the place of traditional systems. Westernization process which started in late decades of Ottoman Empire carried on in republican era.

Since the effects of westernization are related to the center-periphery, it first intensively became prominent in Istanbul. However the reflections at different levels in the cities of Anatolia were also observed. In the cities, effective changes were visible in whole city from architecture to the physical structure of streets, from city form to open-green areas. With the effects of political transformations on urban space, the function and form of the green areas changed; this change and transformation gained visibility in green areas. In the westernization process in which the social dynamics are reflected in the urban space, new green areas were arranged in the western style. The westernization movement reflected to the major design concept of green areas which bring different identity to the green areas.

Public space which has an important place in urban space is green areas. Public parks and gardens were built, inspired by the Folk Gardens in France; these gardens, which were located in Istanbul and other Ottoman cities, were called "Nation Gardens". In this context, the transformations of the green areas in the Ottoman Empire, in the westernization process are seen on the basis of the Nation Gardens and parks. Nation Gardens were basic forms of westernization that are similar in terms of the period and method they were made.

Konya is a synthesis of Seljukian and Ottoman culture in terms of social, cultural, economic, art, architecture and landscape architecture. Konya, located in the Central Anatolia, due to its location has served as a bridge between the east and west and between the north and the south by linking the Black Sea and Central Anatolia regions to the South-East and Mediterranean regions. In this study; an explanation was made about Nation Gardens which was presented to the use of people in different cities with the effect of change and westernization in green areas during the late Ottoman period; also information was given about the urban features of Konya and the Konya Nation Garden during the Ottoman period. 


\section{KAYNAKÇA}

Arşiv Belgeleri

VEKAM Kütüphanesi ve Arşivi, Envanter No: 0819

\section{Karar Yazıları}

Konya Kültür Varlıklarını Koruma Bölge Kurulu 05.02.2013 tarih ve 1103 sayılı kararı.

\section{Web Sayfaları}

Eski İstanbul Fotoğrafları Arşivi, Erişim tarihi: 03.05.2018, http://www.eskiistanbul.net/

Konya Büyükşehir Belediyesi Eski Konya Fotoğrafları Arşivi, Erişim tarihi: 05.05.2018, http://www.konya.bel.tr/sayfadetay.php?sayfaID=240,

Tevfik Ataberk'in Fotoğraf Arşivi, Erişim tarihi: 06.05.2018, https://www.facebook.com/tevfikataberk

Yaşar Barışık'ın Fotoğraf Arşivi, Erişim tarihi: 06.05.2018. https://www.facebook.com/yasar.barisik1

\section{Yayınlanmış Eserler}

AKGÜL, Alphan (2016), "Osmanl-Türk Romanında İstanbul Tasvirleri ve Perspektif Kullanımı", Osmanlı İstanbul'u Sempozyumu IV, 20-22 Mayıs 2016, İstanbul, 495-520.

AKTAŞ YASA, Azize (1998), "Selçuklu Dönemi Konya'sında Şehrin Yeşil Dokusu”, Vakıflar Dergisi, 27: 6574.

BAYRAKTAR, Adile Nuray (2013), “Başkent Ankara'da Cumhuriyet Sonrası Yaşanan Büyük Değişim: Modern Yaşam Kurgusu ve Modern Mekanlar", Ankara Araştırmaları Dergisi, 4(1): 67-80.

ÇAYCI, Ahmet (2006), “Osmanlı Seyyahlarının İzlenimleriyle Konya ve Çevresi,” Selçuk Üniversitesi İlahiyat Fakültesi Dergisi, 21: 15-146.

ÇELIK, Filiz, (2015), "Selçuklu Sarayı Gül Bahçesi”, I. Ulusal Peyzaj Mimarlığı Kongresi, 15-17 Ekim 2015, Ankara, 4-24.

ÇELIK, Filiz, (2016), "Tarihi Dede Bahçesi”, I. Ulusal Pemkon Konferansı-Türk Bahçeleri, 23-25 Mayıs 2016, İstanbul, 30-41.

DOĞAN, M. Sabri (2015), “Millet Bahçesi”, Konya Ansiklopedisi, C.6, 392-393.

DOĞAN, M. Sabri (), "Yirminci Yüz Yıl Başlarında Konya”, Erişim tarihi: 23.01.2018, http://www.konya.bel.tr/sayfadetay.php?sayfaID=260

ELDEM, Sedat Hakkı (1976), Türk Bahçeleri, İstanbul: Kültür Bakanlığı Türk Sanat Eserleri 1.

GÜRBÜZ, Elif, (2009), Tarih İçerisinde İstanbul'daki Mesire Olgusu ve Mesire Alanlarının Geçirdikleri Değişimin Kağıthane Mesiresi Örneği Üzerinden İrdelenmesi, İstanbul: İstanbul Teknik Üniversitesi, Fen Bilimleri Enstitüsü: (yayımlanmamış yüksek lisans tezi).

GÜRKAŞ, Tayfun, (2003), “Erken Cumhuriyet Türkiye'sinde Kamusal Yeşil Alanın Doğuşu”, İstanbul: Yıldız Teknik Üniversitesi, Fen Bilimleri Enstitüsü, (yayınlanmamış yüksek lisans tezi).

GÜRKAŞ, Tayfun, (2004), "Modernleşen Osmanlı Parklarının Üsküdar'daki Erken İki Örneği: Millet Bahçesi ve Doğancılar Parkı", Üsküdar Sempozyumu I, 22-23 Mayıs 2003, İstanbul, 409-416.

GÜRKAŞ, Tayfun (2009), “Bir Mimarlık Tarihi Alanı Olarak Türkiye'de Peyzaj Mimarlığı Tarihi ve Peyzaj Mimarlığ1-Devlet İdeolojisi İlişkisi”, Türkiye Araştırmaları Literatür Dergisi, 7(13): 171-190.

İGÜS Esma - İSMAİLOĞLU, Hayriye (2016), "Osmanlı Kenti İstanbul'u Yikmak ve Yeniden Yapmak Paradoksu: Menderes Yikımları", Osmanlı İstanbulu IV, 20-22 May1s 2016, İstanbul, 115-158.

KARAOSMANOĞLU, Yakup Kadri (1999),Vatan Yolunda, İstanbul: İletişim Yayınları.

KARPUZ, Haşim (1996), Fotoğraflarla Geçmişte Konya, Konya: Konya Büyükşehir Belediyesi Kültür Müdürlüğü Yayınları.

KİRAZ, Ersel (2018), “Osmanlı Devletinde Modern Dönüşüm Evrelerinin Kamu Üzerindeki Etkileri”, Academic Review of Humanities and Social Science, 1(1): 1-16.

KOCA, Feray (2005), “Türkiye' de Geleneksel Yerleşim Örüntülerinin Özgün Karakter ve Kültürel Mirasını Koruma Anlayışına Ontolojik Bir Yaklaşım", Planlama, 25(1): 32-43.

MEMLÜK, Yalçın (2009), Bulvarın Yeşil Parçaları, (ed. H. Çağatay Keskinok), Cumhuriyet Devrimi'nin Yolu: Atatürk Bulvarı, Ankara: Koleksiyoncular Derneği Yayını.

MEMLÜK, Yalçın, (2013), "Anadolu'da Türk Bahçesi ve Bahçe Kültürü", Plant Dergisi, 51, Erişim tarihi: 8.01.2018, http://www.plantdergisi.com/yazi-profdryalcin-memluk-51.html 
MEMLÜK, Yalçın, (2017), Osmanlı Modernleşmesi ile Ortaya Çıkan Bir Kentsel Mekan Olarak Millet Bahçeleri, Erişim tarihi: 20.02.2018, http://www.skb.gov.tr/osmanli-modernlesmesi-ile-ortaya-cikanbir-kentsel-mekan-olarak-millet-bahceleri-s25212k/

MUŞMAL, Hüseyin (2016), Osmanlı Döneminde Konya, (ed. Caner Arabacı), Kısa Konya Tarihi, Konya: TMMOB Makine Mühendisleri Odası Konya Şubesi.

NALBANT, Mehmet (2016), “Türkiye'de Kentsel Mekanlarda Kamusal Alanın Konumu: Tarihsel Perspektiften Bir Değerlendirme", BEU Akademik İzdüşüm, 1(1): 12-27.

NUHOĞLU, Arzu, KOYUNOĞLU, Balin, TAN, Elif (2016), “Türkiye Tasarım Kronolojisi Peyzaj”, İstanbul: 3. İstanbul Tasarım Bienali, 22 Ekim- 20 Kasım 2016.

ODABAŞI, A. Sefa (1998), 20. Yüzyıl Başında Konya'nın Görünümü, Konya: T.C. Konya Valiliği İl Kültür Müdürlüğü Yayınları.

OKTAÇ, A. Deniz (2003), “Selçuklu ve Osmanlı Dönemi Konya'sında Bağlar ve Bağ Mülkiyeti”, Osmanlı Döneminde Konya, Konya: T.C. Konya Valiliği İl Kültür ve Turizm Müdürlüğü Yayını.

ÖZCAN, Görgün (2017), Osmanlı Şehirciliği ve Vakıflar, İstanbul: Yeditepe Yayınevi.

ÖZGÜÇ ERDÖNMEZ, İ. Müge, AYDOĞDU ÜNLÜ, S. Aslı (2009), “Kentsel Açık Alanları Etkileyen Sanat Akımlarının Türkiye'deki Yansımaları: İstanbul Örneği," İstanbul Üniversitesi Orman Fakültesi Dergisi, 59-2: 33-50.

SELVİ ÜNLÜ, Tülin, (2012), "Cumhuriyet Modernleşmesi ve Mersin'de Kamusal Mekana Etkisi”, Osmanlı Dünyasında Kültürel Karşılaşmalar ve Sanatsal Yansımaları: Prof. Dr. Filiz Yenişehirlioğlu'na Armağan 14-16 Kasım 2012, Ankara, 251-258.

TANYELİ, Uğur, (2005), "Kamusal Mekan-Özel Mekan: Türkiye'de Bir Kavram Çiftinin İcadı", Genişleyen Dünyada Sanat, Kent ve Siyaset: 9. Uluslararası İstanbul Bienali, 16 Eylül-30 Ekim 2005, İstanbul, 199209.

TONGA, Necati (2014), “Cumhuriyet Ankara'sının Devraldığı Edebî Miras: Cumhuriyet Dönemi'ne Kadar Ankara'daki Edebiyat Hayatı ve Edebiyat Mahfilleri”, Ankara Araştırmaları Dergisi, 2(2): 184-202.

TOPÇU, Kadriye (2011), “Kent Kimliği Üzerine Bir Araştırma: Konya Örneği”, Uluslararası İnsan Bilimleri Dergisi, 8(2): 1048-1072.

TURGUT GÜLTEKIN, Nevin, (2015). “Batılılaşmanın Uzantısında Kent Bahçeleri; Giresun Memleket-Millet Bahçesi", I. Ulusal Peyzaj Mimarlığı Kongresi, 15-17 Ekim 2015, Ankara, 7-14.

YÖRÜK, Doğan (2017), “XVI. Yüzyılda Konya Şehir Ekonomisi,” SUTAD, 42: 353-379. 